\title{
PERAN KONSELOR DALAM KONSELING MULTIBUDAYA UNTUK MEWUJUDKAN KESETARAAN GENDER
}

\author{
Khusnul Khowatim \\ Sekolah Menengah Pertama Zainudin Waru Sidoarjo \\ khusnulkhowatim2@gmail.com
}

\begin{abstract}
Abstrak
Berbicara tentang konseling multikultural, tentunya terdapat kebudayaan yang beragam, dimana konselor dalam hal ini dituntut untuk memiliki kemampuan dalam melakukan konseling multikultural pada era saat ini. Salahsatu tema yang dibahas dalam artikel ini ialah perwujudan kesetaraan gender. Kesetaraan gender tentu sangat diperlukan agar tidak terdapat ketimpangan antara kaum lelaki dan perempuan. Dalam artikel ini akan membahas tentang beberapa hal, yaitu diantaranya kompetensi yang harus dimiliki konselor pada saat ini untuk mewujudkan kesetaraan gender dalam konteks multibudaya, konseling mmultikultural, situasi yang terjadi pada konseling multikultural, karakteristik konselor yang efektif secara multikultural, pengembangan diri konselor multikultural, kesetaraan gender, serta upaya yang dapat dilakukan konselor untuk dapat mewujudkan kesetaraan gender menggunakan studi literatur.
\end{abstract}

Kata Kunci: Multikultural, Kesetaraan Gender, Peran Konselor

\begin{abstract}
Speaking of multicultural counseling, of course there are diverse cultures, where counselors in this case are required to have the ability to conduct multicultural counseling in the current era. One of the themes discussed in this article is the realization of gender equality. Gender equality is certainly very necessary so that there are no inequalities between men and women. In this article we will discuss a number of things, including the competencies that counselors must have at the moment to realize gender equality in a multicultural context, multicultural counseling, situations that occur in multicultural counseling, characteristics of multicultural effective counselors, self-development of multicultural counselors, equality gender, and efforts that counselors can make to realize gender equality used literature review.
\end{abstract}

Keywords: Multiculturalism, Gender Equality, Role of Counselors

\section{PENDAHULUAN}

Usaha untuk meningkatkan mutu pendidikan pada setiap jenjang pendidikan dapat terlaksana dan mencapai hasil yang optimal bila proses pembelajaran berlangsung dalam suasana kelas yang kondusif serta dibina dan dibimbing oleh guru yang profesional. Terwujudnya kesetaraan dan keadilan gender ditandai dengan tidak adanya diskriminasi antara perempuan dan laki-laki, sehingga mereka dapat mengakses, serta diberi kesempatan untuk berpartisipasi dan kontrol didalam pendidikan dan memperoleh manfaat yang setara dan adil dalam pendidikan.

Nilai kemanusiaan terwujud dengan adanya pemerataan yang tidak mengalami bias gender. Masalah pendidikan antara anak perempuan dan anak laki-laki hendaknya harus seimbang, anak perempuan dan anak laki-laki sebagaimana harus punya hak/kesempatan yang sama untuk sekolah lebih tinggi. Kesetaraan dan keadilan gender dapat juga disebut dengan istilah kemitrasejajaran yang harmonis antara laki-laki dan perempuan dalam penddikan, artinya laki-laki dan perempuan mempunyai hak dan kewajiban, kedudukan, peranan serta kesempatan yang sama dalam berbagai bidang kehidupan terlebih di dalam pendidika. Semua itu dilandasi atas dasar saling menghormati, saling menghargai, saling membantu, saling mengisi dan sebagainya dalam kehidupan berkeluarga, bermasyarakat, berbangsa dan bernegara.

Dalam mewujudkan kesetaraan dan keadilan gender diperlukan pula peran guru bimbingan dan konseling atau biasa yang disebut dengan konselor dalam membuat layanan bimbingan dan konseling yang berhubungan dengan kesetaraan gender. Seperti layanan konseling multicultural, didalam konseling ini membahas tidak hanya pada keberagaman siswa, tetapi juga perbedaan budaya yang disandang antara konselor dengan siswanya.

Dalam layanan konseling, keragaman budaya menyadarkan Guru bimbingan dan konseling (konselor) tentang pentingnya kesadaran multikultural dalam menghadapi perbedaan, sekecil apapun perbedaan tersebut. Guru bimbingan dan konseling perlu mengubah persepsi mereka, mencukupkan diri dengan pengetahuan tentang budaya, memahami bentuk-bentuk diskriminasi, stereotip dan rasisme (Holcomb-McCoy, 2004,294). Guru bimbingan dan konseling sekolah, harus menghargai keberagaman konseli (Depdiknas, 2007, 12), Konselor perlu memiliki kesadaran multikultural yaitu menghargai perbedaan dan keragaman nilai- nilai, keyakinan-keyakinan, menyadari adanya bias-bias dan kesadaran akan keterbatasan diri dalam hal budaya. Guru bimbingan 
dan konseling memahami pandangan hidup dan latar belakang budaya diri dan konseli serta mengembangkan strategi konseling yang sesuai budaya.

Konselor tidak hanya memerlukan pengetahuan multikultural melainkan juga memerlukan kesadaran. Karena Kesadaran dan pengetahuan multikultural mungkin berhubungan satu sama lain, Konselor dengan kesadaran multikultural tetapi kurang dalam pengetahuan mungkin memiliki keterbatasan pengetahuan. Dalam konseling multikultural diperlukan untuk menjaga konteks budaya klien ras / etnis minoritas. Konselor dengan pengetahuan multikultural tetapi tidak kesadaran mungkin tidak menyadari bias budaya mereka sendiri, sehingga tidak memiliki kompetensi konseling lintas budaya. (DW Sue \& Sue, 1990.2008) mengusulkan bahwa latar belakang demografis seseorang, seperti jenis kelamin, bisa menjadi langkah penting dalam meningkatkan kompetensi konseling multikultural konselor. Bahkan, Wester (2008) menyatakan bahwa tanpa memahami gender atau peran sikap, konselor mungkin mengalami kesulitan memberikan layanan yang peka budaya terhadap beragam populasi secara budaya konselor yang kompeten memperoleh kompetensi konseling multikultural melalui pelatihan multiculral untuk bekerja secara efektif dengan berbagai kelompok.

Didalam konseling multikultural ini menuntut konselor untuk dapat memberikan layanan yang sesuai dengan perbedaan kondisi konseli. Namun tidak berarti konselor dapat memilih siswa tertentu yang mendapatkan layanan bimbingan dan konseling, misalkan konselor hanya memberikan layanan pada siswa laki-laki, pada siswa yang memiliki masalah, siswa yang berprestasi, dan lainnya. Sedangkan perbedaan budaya, nilai-nilai, dan keyakinan antara konselor dengan siswa sebagai konseli mengharuskan konselor memiliki kebijaksanaan dalam layanan bimbingan dan konseling sehingga konselor tidak memaksakan nilai budaya dan agamanya pada konseli.

\section{METODE}

Penelitian ini menggunakan metode kajian literature untuk menjawa pertanyaan penelitian. Literature yang digunakan berupa buku dan artikel yang telah ditentukan sebelumnya.

\section{PEMBAHASAN}

Konselor profesional multikultural memiliki yang nanamya adanya kepekaan budaya, menghargai budaya, melepaskan diri dari bias-bias budaya, menghargai diversitas budaya, ketrampilan komunikasi yang responsive secara kultural, adanya kesadaran bahwa individu dan kelompok yang dihadapi memiliki keunikannya masing - masing. Konselor memiliki pengetahuan, keterampilan. Seluruhnya terintegrasi dalam mencapai tujuan dari pelayanan multikultural. Seperti: adanya kesadaran konselor bahwa dirinya harus mampu merasa nyaman dalam keadaan/semua perbedaan yang mungkin sangat jelas antar dirinya, dan konseli, nyaman dalam menghadapi ras, etnik, gender serta budaya yang tidak sama. Pendidik dalam hal ini adalah seorang Konselor yang menjadi komponen penting dalam proses pendidikan yang kaitannya dengan kebudayaan. Pendidik dalam hal ini adalah seorang Konselor yang menjadi komponen penting dalam proses pendidikan yang kaitannya dengan kebudayaan. Pemahaman terhadap budaya dalam rangka bekerja dengan konseli/peserta didik tanpa memaksakan nilai-nilai mereka, menyinggung konseli, atau perilaku non verbal pada konseli yang salah diinterpretasikan. Berkaitan dengan hal diatas, penting bagi seorang konselor yang memiliki banyak kompetensi yang akan memberikan arah dalam pelaksanan dan kegiatan konseling dengan keberagaman budaya konselinya. Kompetensi terhadap praktek/kegiatan konseling tentu akan melibatkan pemahaman dan kesadaran konselor terhadap budaya yang dimilikinya dan konselinya. Menurut Kertamuda (2011) Kesadaran budaya (cultural awareness) merupakan salah satu dimensi yang penting untuk dimiliki oleh seorang konselor, karena dimensi ini perlu dimiliki oleh konselor agar dapat memiliki pemahaman dan kesadaran bahwa faktor budaya yang dimilikinya (ras, gender, nilai-nilai, kelas sosial, dan lain-lain) akan mempengaruhi perkembangan diri dan pandangan terhadap dirinya.

Kartadinata (2005) menyebutkan bahwa sebagai pendidik psikologis, terutama konselor harus memiliki kompetensi dalam hal ini:

a. Memahami kompleksitas interaksi individulingkungan dalam ragam kontesk sosial budaya.

b. Menguasai ragam bentuk intervensi psikologis baik antar maupun intra pribadi dan lintas budaya.

c. Menguasai strategi dan teknik asesmen yang memungkinkan dapat difahaminya keberfungsian psikologis individu dan interaksinya dengan lingkungan.

d. Memahami proses perkembangan manusia secara individual maupun secara sosial.

e. Memegang kokoh regulasi profesi yang terinternalisasi ke dalam kekuatan etik profesi yang mempribadi.

f. Memahami dan menguasai kaidah-kaidah dan praktek pendidikan.

Dalam mengembangkan potensi konselor dalam bimbingan dan konseling multikultural adapun Peran konselor dalam bimbingan dan konseling multikultural yaitu :

a. Konselor mampu membantu konseli untuk menganalisis peran gender dengan tujuan mengeksplorasi berbagai dampak dari peran gender yang selama ini menjadi keyakinannya dan Memiliki perspektif multikultural.

b. Konselor mempunyai berbagai orientasi teoretik yang berkaitan dengan tidak memihak pada salah satu gender (gender fair), fleksibilitaskultural, mudah berinteraksi dan life span oriented.

c. Konselor mampu menekankan pada pemahaman individu dan pengaruhnya terhadap perkembangannya. 
Perubahan individu diharapkan dapat berpengaruh pada gender role socialization, masyarakat, keluarga dan sistem yang lain. Segala kompetensi dan kualitas konselor tidak akan efektif apabila dalam proses konseling konselor itu sendiri tidak memiliki pemahaman yang tinggi terhadap kliennya yang multicultural dalam era globalisasi sekarang ini. Sebagai konselor mempunyai asas kekinian yang mengharuskan konselor mempunyai kemampuan dalam menyesuaikan segala sesuatu yang berhubungan dengan kliennya untuk selalu update pada era globalisasi sekarang ini dan untuk mengembangkan kesadaran budaya (cultural awareness), konselor sebaiknya meningkatkan penghargaan diri terhadap perbedaan budaya. Sehingga ketika berhadapan langsung dengan konslei yang berbeda budaya konselor sudah sangat siap dan sudah memiliki wawasan terhadap konseling multibudaya/multicultural.

\section{Konseling Multikultural}

Konseling pada umumnya merupakan hubungan dua orang, yang secara normal melibatkan konselor dan konseli.dan selama bertahun-tahun bahwa terciptanya empathetic terhadap konseli cukup membuat hubungan konseling yang efektif (Ivey, 1986; Dayaksini \& Yuniardi, 2008: 175). Namun seiring dengan perubahan sistem kehidupan masyarakat, terutama berbagai perubahan dalam kehidupan sosial-budaya seperti nilainilai dan keyakinan-keyakinan yang mulai bergeser, bahkan memudar, perkawinan antar ras/ etnik/ suku/ budaya baik berasal dari bangsa yang sama maupun antar bangsa, perubahan kebijakan pendidikan, perubahan gaya kepemimpinan, dan lainnya juga berimplikasi bagi model dan pendekatan yang dipakai dalam layanan konseling.

Jika berpijak pada lingkup multikultural, hubungan konseling tidaklah sederhana, sebab masingmasing konseli membawa suatu latar belakang historis dan budaya khusus yang memiliki implikasi kuat bagi hasil konseling.oleh karenanya pemahaman tentang konseling multikultural sangat diperlukan. Konseling multikultural menurut VonTress (1988) dalam Dayaksini \& Yuniardi (2008: 175) merupakan "konseling di mana konselor dan konselinya berbeda secara kultural karena proses sosialisasi yang berbeda dalam budaya, subkultur, rasial, etnik, atau sosial-ekonomi". Sementara Sue, dkk. (1982) menggambarkan konseling multikultural sebagai hubungan konseling di mana konselor dan konseli berbeda latar belakang budaya, nilai-nilai, dan gaya hidup. Di sini istilah multikultural cenderung lebih diminati karena sama sekali tidak menyiratkan adanya keunggulan satu kultur di atas kultur lainnya.

Heims \& Cook (1997; Sciarra, 2004: 144) merinci konsep kunci dalam konseling multikultural: Haims \& Cook menyebutnya dengan konsep kunci karena tidak mungkin konselor dapat menyelenggarakan layanan konseling multikultural jika tidak dapat memahami istilah atau konsep yang terhimpun dalam konseling multikultural itu sendiri. Konselor akan menghadapi berbagai persoalan latar belakang budaya yang dibawa oleh konselinya. Apakah konseli seorang yang merasa tertindas karena ia minoritas, apakah konseli disepelekan karena ia bagian dari ras tertentu, apakah konseli berpikir untuk bertindak di luar kebiasaan lingkungan sosial-budayanya. Begitu pula dengan konselor, apakah dirinya merasa kesulitan saat melayani konseli yang berbeda secara kultural dengannya, apakah konselor selalu merasa tidak nyaman saat konseli mengungkapkan nilai yang berbeda dengan nilai yang diyakini konselor, dan apakah konselor akan menjadi netral nilai dalam suasana konseling multikultural. Pertanyaan-pertanyaan tersebut dapat konselor jawab jika ia memahami konsep dari konseling multikultural dan mau mengambil sikap untuk terus melakukan pengembangan diri.

Dengan demikian, konseling multikultural dapat dipahami sebagai "suatu bentuk konseling di mana konselor dengan konseli (perorangan/ kelompok) memiliki perbedaan-perbedaan nilai dan keyakinan yang berasal dari lingkungan historis, sosial, budaya, agama, perkembangan fisik (usia dan seks biologis), dan peran identitas-gender". Musrifah (Mufrihah, 2014:82) menyatakan situasi yang terjadi dalam konseling multikultural meliputi :

a. konselor memiliki budaya dan konseli juga membawa budayanya sendiri

b. mungkin saja konselor dan konseli berasal dari sistem budaya yang sama namun berbeda secara usia, peran dalam anggota masyarakat, status perkawinan, orientasi seksual, dan kelas sosialekonomi

c. konselor dan konseli berasal dari lingkup budaya yang sama atau berbeda namun perlu menyesuaikan dirinya dengan praktik budaya yang berlaku dalam lingkungan tempat layanan konseling diselenggarakan.

\section{Karakteristik Konselor Efektif Secara Multikultural}

Musrifah (Mufrihah, 2014:82) menyatakan ada beberapa karakteristik konselor yang dapat menjadikan konseling multikultural menjadi efektif:

a. Mengenali nilai-nilai dan asumsi yang mereka pegang sebagai dasar menilai perilaku manusia yang diinginkan atau tidak diinginkan

b. Menyadari karakteristik umum dari konseling

c. Dapat berbagi pandangan dengan konseli tanpa meniadakan hakhaknya

d. Dapat menerapkan metode konseling yang eklektik

e. Memiliki kesadaran dan kepekaan terhadap budaya yang

f. Menyadari nilai-nilai dan bias yang dapat memengaruhi konseli yang berbeda budaya dengan diri konselor

g. Merasa tidak terganggu dengan perbedaan dirinya dengan konseli yang berkaitan dengan ras dan kepercayaan

h. Menguasai informasi dan pengetahuan spesifik tentang kelompok tertentu yang bekerja sama dengan diri konselor

i. Mampu menghasilkan tanggapan verbal dan non-verbal yang luas 
j. Mampu mengeirimkan dan menerima pesan baik secara verbal maupun non-verbal secara wajar dan teliti.

Pemahaman terhadap konseling multikultural dapat mengantarkan konselor untuk menyadari hal atau keterampilan apa saja yang perlu dimiliki atau mungkin perlu dikembangkan agar dapat memaksimalkan terselenggaranya konseling multikultural yang efektif sesuai dengan prinsip bimbingan dan konseling. Lebih lanjut karakteristik konselor yang efektif secara kultural juga akan sangat memengaruhi keterampilan konselor dalam praktik layanan konseling multikultural yang tidak dapat muncul begitu saja dalam diri konselor, namun perlu latihan dan evaluasi secara berkelanjutan dan berkesinambungan.

\section{Pengembangan Diri Konselor Multikultural}

Musrifah (Mufrihah, 2014:83) menyatakan Sejalan dengan kompetensi yang harus dimiliki konselor dalam berbagai bidang yang berkenaan dengan layanan konseling, maka untuk mengembangkan diri sebagai konselor multikultural diperlukan awareness, knowledge, and skills.

1. Multicultural Awareness

konselor perlu memiliki kesadaran terhadap perilakunya yang berhubungan dengan konseli yang berbeda secara kultural dengan dirinya (McCoy, 2013: 8). Perilaku konselor akan memengaruhi persepsi konseli sekaligus arah dari konseling yang sedang berjalan. Jika konselor tidak menyadari bahwa karateristik perilakunya merupakan bentukan dari kebudayaan asalnya maka akan dapat memengaruhi perilaku konseli selama sesi konseling.

2. Multicultural Knowledge

Melaksanakan konseling multikultural berarti konselor menerima konsekuensi berupa pentingnya memiliki pengetahuan tentang konsep multikultural sehingga dapat menjadi bagian dalam layanan konseling. Pengetahuan yang harus dimiliki konselor kaitannya dengan konseling multikultural ialah kebudayaan, ras, etnik, etik dan emik, kelompok minoritas dan mayoritas, dan tentunya prinsipprinsip multikultralisme. Pengetahuan tersebut bisa didapatkan dari para konseli yang dilayani, melakukan studi/ kajian literatur, dan melakukan penelitian yang berhubungan dengan permasalahan multikultural para siswanya.

3. Multicultural Skills:

Keterampilan multikultural dimaksudkan untuk membantu konseli mengembangkan teknik dan strategi yang tepat, yaitu efektif bagi siswa yang berbeda-beda secara kultural dengan siswa lain dan dengan konselor (McCoy, 2013: 12). Hal demikian dilakukan karena bisa saja teknik dan strategi tertentu baik bagi siswa tertentu, atau dinilai efektif oleh konselor, namun ternyata tidak demikian saat dilakukan oleh siswa lain dengan latar pada kepiawaian konselor sesuai dengan kadar pengetahuan dan tingkatan kesadaran konselor akan isu-isu multikulturalisme.

\section{Kesetaraan Gender}

Gender merupakan salah satu isu yang hangat dan menarik diperbincangkan istilah gender mengandung arti seperangkat sikap, peran tanggung jawab,fungsi,hak dan perilaku yang melekat pada diri laki - laki dan perempuan akibat bentukan budaya atau lingkungan masyarakat tempat dimana manusia itu tumbuh dan dibesarkan. Mengacu pada pendapat Mansour Faqih, Gender adalah suatu sifat yang melekat pada laki-laki maupun perempuan yang dikonstruksi secara sosial maupun kultural. Misalnya bahwa perempuan itu lemah lembut, cantik, emosional, dan sebagainya. Sementara laki-laki dianggap kuat, rasional, jantan, perkasa, dan tidak boleh menangis. Ciri dan sifat itu sendiri merupakan sifat-sifat yang dapat dipertukarkan. Perubahan ciri dan sifat tersebut dapat terjadi dari waktu ke waktu dan dari tempat ketempat yang lain, juga perubahan tersebut bisa terjadi dari kelas ke kelas masyarakat yang berbeda. Secara umum, pengertian Gender adalah perbedaan yang tampak antara laki-laki dan perempuan apabila dilihat dari nilai dan tingkah laku. Gender adalah perbedaan yang tampak pada laki-laki dan perempuan apabila dilihat dari nilai dan tingkah laku. Gender merupakan suatu istilah yang digunakan untuk menggambarkan perbedaan antara laki-laki dan perempuan secara sosial.

Gender adalah kelompok atribut dan perilaku secara kultural yang ada pada laki-laki dan perempuan. Dengan demikian gender sebagai suatu konsep merupakan hasil pemikiran manusia atau rekayasa manusia, dibentuk oleh masyarakat sehingga bersifat dinamis dapat berbeda karena perbedaan adat istiadat, budaya, agama, sitem nilai dari bangsa, masyarakat, dan suku bangsa tertentu. Selain itu gender dapat berubah karena perjalanan sejarah, perubahan politik, ekonomi, sosial dam budaya, atau karena kemajuan pembangunan.

Dengan demikian gender tidak bersifat universal dan tidak berlaku secara umum, akan tetapi bersifat situasional masyarakatnya. Cara pandang untuk melihat keterkaitan peran-peran gender laki-laki dan perempuan di masyarakat dengan ketimpangan yang ditimbulkannya, serta upaya untuk mendorong transformasi sosial yang lebih adil, baik pada tataran pengetahuan maupun aksi sosial, ini disebut perspektif keadilan gender.

Sebagai konseling yang sensitif gender, maka prinsip dari konseling ini adalah sebagai berikut:

a. Mengintegrasi konsep gender dalam aspek konseling

b. Mempertimbangkan problem individu disesuaikan dengan konteks sosial.

c. Aktif membantu untuk mengubah pengalaman individu atas ketimpangan gender yang dialami.

d. Menekankan kerjasama dalam konseling

e. Menghormati individu dalam membuat pilihan

Setelah memahami definisi gender maka selanjutnya adalah memahami konsep kesetaraan gender. Menurut Instruksi Presiden Republik Indonesia Nomor 9 Tahun 2000 Tentang Pengarusutamaan Gender Dalam 
Pembangunan Nasional, kesetaraan gender adalah kesamaan kondisi bagi lakilaki dan perempuan untuk memperoleh kesempatan dan hak-haknya sebagai manusia, agar mampu berperan dan berpartisipasi dalam kegiatan politik, ekonomi, sosial budaya, pertahanan dan keamanan nasional, dan kesamaan dalam menikmati hasil pembangunan tersebut. Sedangkan keadilan gender adalah suatu proses untuk menjadi adil terhadap laki-laki dan perempuan.

Kesetaraan gender merupakan suatu kondisi, dimana perempuan dan lelaki menikmati status yang sama, dan memiliki kondisi dan potensi yang setara sama untuk merealisasikan haknya sebagai manusia, serta memiliki hak yang sama pula dalam berkontribusi pada pembangunan nasional, politik, ekonomi, sosial atau budaya. Empat asumsi yang mendasari teori ketimpangan gender :

a. Perempuan mendapatkan posisi yang lebih rendah dibanding laki-laki. Dalam pandangan masyarakat, lelaki dan perempuan bukan hanya berbeda jenis kelamin, tetapi juga berbeda posisi sosial.

b. Organisasi sosial dalam masyarakat memaksa terjadinya perbedaan peranan posisi perempuan dan laki-laki. Hal ini di tunjukan bahwa pada kedudukan tertentu atau bagian tertentu harus seorang lelaki atau harus seorang perempuan.

c. Kekurangberdayaan perempuan dalam merealisasikan kebutuhannya dan aktualisasi dirinya.

d. Laki-laki dan perempuan akan fair dan setara hanya ketika dalam struktur masyarakat yang bersifat egaliter.

Di era yang semakin maju maka akan diprediksi kesetaraan gender ini melahirkan hal-hal sebagai berikut: (Hubeis dalam Mawardi, 2018)

a. Perbedaan peran atau tradisi dalam hal perbedaan seksual antara laki-laki dan perempuan akan memudar, sehingga tidak nampak jelas pembedanya. Hal ini tentu akan menimbulkan ketidak seganan perempuan dalam penyampaikan perasaan atau hasrat seksualnya. Pada lingkungan sekolah, hal ini akan berdampak pada topik obrolan para siswi yang tak segan berbau seksualitas.

b. Kesetaraan gender mendukung peran wanita menjadi wanita karir atau pekerja, dengan demikian akan terdapat peningkatan jumlah wanita perkerja. Begitu juga sebaliknya, lelaki pengangguran juga akan semakin meningkat. Pada lingkungan sekolah, hal tersebut akan meningkatkan jumlah siswi yang rajin bekerja, mengerjakan tugas, gotong royong, dan memimpin. Negitu juga sebaliknya, akan menurunkan tingkat keberkerjaan siswa laki-laki dan berkecenderungan tidak berperan.

c. Sangat dimungkinkan jika seorang suami istri sama-sama memiliki pekerjaan, tentu akan menurunkan waktu berkumpul bersama keluarga, bahkan berpisah tempat tinggal. Hal tersebut memungkinkan keluarga menjadi tidak utuh.

Pemahaman peserta didik serta keikut sertaan peserta didik terhadap kesetaraan gender yang baik tentu harus diperhatikan dengan baik oleh para konselor, sehingga konselor mampu memfasilitasi peserta didik dalam hal kesataraan gender. Beberapa Upaya yang dapat konselor lakukan pada era ini adalah:

a. Membuat media pembelajaran terkait kesetaraan gender yang inovatif dan kreatif. Dengan demikian media tersebut dapat menarik minat dan perhatian peserta didik. Media yang dapat di buat misal, modul panduan pelatihan kesetaraan gender yang telah didesain dan dikemas dengan menarik. (Youarti, Radjah \& Handarini 2019)

b. Memperlihatkan film Nyai Ahmad Dahlan untuk mempegaruhi persepsi peserta didik terhadap kesetaraan gender. Penelitian yang dilakukan membuktikan bahwa terdapat pengaruh yang besar dan signifikan dari penayangan film tersebut terhadap persepsi peserta didik. (Liansari, 2018)

c. Turut serta mewujudkan pendidikan berbasis kesetaraan gender dengan berbagai cara, salahsatunya membuat program bimbingan dan konseling berbasis kesetaraan gender. Kolaborasi dengan pihak lain di lembaga sekolah diperlukan agar tidak ada ketimpangan gender baik dalam proses pendidikan maupun penerimaan peserta didik baru dalam suatu jurusan tertentu. (Ulya 2018)

\section{PENUTUP}

\section{Simpulan}

Dalam mewujudkan kesetaraan dan keadilan gender diperlukan pula peran guru bimbingan dan konseling atau biasa yang disebut dengan konselor dalam membuat layanan bimbingan dan konseling yang berhubungan dengan kesetaraan gender. Seperti layanan konseling multicultural, didalam konseling ini membahas tidak hanya pada keberagaman siswa, tetapi juga perbedaan budaya yang disandang antara konselor dengan siswanya. Perubahan individu/konseli diharapkan dapat berpengaruh pada gender role socialization, masyarakat, keluarga dan sistem yang lain. Segala kompetensi dan kualitas konselor tidak akan efektif apabila dalam proses konseling konselor itu sendiri tidak memiliki pemahaman yang tinggi terhadap kliennya yang multicultural dalam era globalisasi sekarang ini.

Sebagai konselor mempunyai asas kekinian yang mengharuskan konselor mempunyai kemampuan dalam menyesuaikan segala sesuatu yang berhubungan dengan kliennya untuk selalu update pada era globalisasi sekarang ini dan untuk mengembangkan kesadaran budaya (cultural awareness), konselor sebaiknya meningkatkan penghargaan diri terhadap perbedaan budaya. Sehingga ketika berhadapan langsung dengan konslei yang berbeda budaya konselor sudah sangat siap 
dan sudah memiliki wawasan terhadap konseling multibudaya/multicultural.

Konselor masa kini tentunya harus memiliki kompetensi tertentu untuk mewujudkan kesetaraan gender dalam konteks multikultural. Dalam pengembangan konselor tersebut diantaranya konselor harus memiliki kesadaran bahwa ia berbeda dengan konseli dalam hal budaya atau kebiasaan, konselor harus memiliki pengetahuan yang luas tentang multikultural dan kesetaraan gender, serta konselor harus dapat mengembangkan teknik dan strategi yang tepat dalam konseling multikultural. Pada masa ini, konselor juga di tuntut untuk inovatif dan kreatif, sehingga dapat menunjang perwujudan SDGs dalam tema kesetaraan gender.

\section{Saran}

Bagi peneliti lanjutan, artikel ini dapat digunakan sebagai referensi untuk melakukan penelitian ataupun membuat latar belakang.

Bagi Konselor atau guru BK, Artikel ini dapat dijadikan bahan bacaan yang dapat membuka fikiran dan memperluas wawasan terutama tentang peran konselor multikultural untuk mewujudkan kesetaraan gender.

Bagi lembaga pendidikan, Artikel ini dapat membuka wawasan bahwa kesertaraan gender juga perlu diwujudkan dalam konteks pendidikan, sehingga artikel ini dapat dijadikan acuan untuk menentukan sistem pembelajaran ataupun penerimaan peserta didik baru terkait kesetaraan gender.

\section{DAFTAR PUSTAKA}

Dayaksini, Tri \& Yuniardi, Salis. 2008.Psikologi Lintas Agama. Malang: UMM Press

Holcomb-McCoy, C., Harris, P., Hines, E. M., \& Johnston, G. 2008. School Counselors' Multicultural Self-Efficacy: A Preliminary Investigation. Journal: Professional School

Instruksi Presiden Republik Indonesia Nomor 9 Tahun 2000 tentang Pengarusutamaan Gender Dalam Pembangunan Nasional

Kertamuda, Fatchiah. 2011. Konselor dan Kesadaran Budaya (Cultural Awareness). Universitas Paramadina. Jakarta.

Latipun. 2008. Psikologi Konseling, Malang: UMM Press.

Liansari, M. (2018). Pengaruh Film Nyai Ahmad Dahlan Terhadap Persepsi Kesetaraan Gender Siswa Kelas XI SMA Aisyiyah 1 Palembang. UIN RADEN FATAH PALEMBANG.

Mansour Faqih, Analisis Gender dan Transformasi Sosial (Yogyakarta: Pustaka Pelajar, 2007), h. 8-9)
Mawardi, M. (2018). GENDER DAN HAK ASASI PEREMPUAN. KOMUNIKA, 1(2), 234-247.

Moule, Jean. 2012. Cultural Competence: A primer for educators.

Wadsworth/Cengage, Belmont: California

Mufrihah, A. (2014). Implikasi prinsip bimbingan dan konseling terhadap kompetensi multikultural konselor. Jurnal Pelopor Pendidikan, 7(1), 73-85

Sanyata, Sigit. Pelatihan Sadar Gender Untuk Mengoptimalkan Layanan Bimbingan dan Konseling Bagi Guru Bimbingan dan Konseling di Kabupaten Kulonprogo. (online) (http://Staffnew.uny.ac.id) diakses pada 17 Maret 2020

Sciarra, D. (2004). School counseling: Foundations and contemporary issues. Belmont, CA: Brooks/Cole.

Sigit Sanyata, Gender Aware Therapy (Gat) : Teknik Konseling Berperspektif Gender, Makalah Disajikan pada Prosiding Seminar Dan Workshop Internasional "Contemporary And Creative Counseling Techniques: How To Improve Your Counseling Skills, And To Be More Creative In Counseling Sessions". SPs UPI. 2011.

Sue, D.W. 1981. Counseling The Culturally Different : Theory and Practice. New York John Wiley and Sons, Inc.

Ulya, I. (2018). Pendidikan Berbasis Kesetaraan Gender: Studi Kebijakan Pemerintah dan Aplikasinya dalam Pendidikan. MAGISTRA: Media Pengembangan Ilmu Pendidikan Dasar dan Keislaman, 4(1), 11-32.

Youarti, I. E., Radjah, C. L., \& Handarini, D. M. (2019). Modul Panduan Pelatihan Kesadaran Kesetaraan Gender bagi Siswa SMP sebagai Upaya Mempromosikan Pendidikan Damai. Jurnal Pendidikan: Teori, Penelitian, dan Pengembangan, 4(10), 1402-1407. 